\title{
Text Possession and Teachers' Pedagogical Practices in the Teaching of Prose Literature-in-English in Some Schools in Ibadan
}

\author{
F.O. Ezeokoli ${ }^{1, *} \&$ Igubor P. ${ }^{1}$ \\ ${ }^{1}$ Department of Teacher Education, University of Ibadan, Nigeria \\ *Corresponding author: Department of Teacher Education, University of Ibadan, Nigeria. \\ E-mail: drezeokoli@yahoo.com
}

Received: November 5, 2013

Accepted: March 26, $2014 \quad$ Online Published: April 2, 2014

doi:10.5430/jct.v3n1p63

URL: http://dx.doi.org/10.5430/jct.v3n1p63

\begin{abstract}
Performance in school examinations has remained one of the reliable indices of the quality of education in many countries. For over two decades in Nigeria, students' performance in most subjects on the school curriculum including Literature-in-English has been persistently declining. A number of explanations are offered for this unsatisfactory situation. Many students experience frustration in their efforts to study Literature due to poor proficiency in the English language as well as non-facilitative methods and strategies adopted by teachers. Studies on the teaching of Literature further revealed that the focus of research was on such issues as methods, strategies and problems of teaching Literature in the secondary school. Only a few studies centered on text possession while little or none seem available on whether the teacher's methods and pedagogical practices were sensitive to students' extent of text possession. The study, therefore, investigated the extent of prescribed text possession by Literature-in-English students as well as whether the level of text possession by students influenced the teacher's methods and pedagogical practices. The descriptive survey research design was adopted in the study. Participants in the study comprised 100 Senior Secondary School II teachers of Literature-in-English and their 500 students in Ibadan metropolis. The participants were selected using purposive random sampling techniques. Three instruments used for the collection of data were: Questionnaire on Students' Possession of Prescribed Prose Literature Texts ( $r=.76)$, Questionnaire on Teachers' Organization of the Teaching of Literature $(\mathrm{r}=.75)$ and Classroom Observation Schedule for the Teaching of Prose Literature $(r=.84)$. Four research questions were answered. Data analysis involved the use of frequency counts and percentages. Results revealed that a majority of the students do not possess the prescribed Literature texts (60.2\% and 65.5\%) for African and non- African novels respectively. Teachers generally adopted the read aloud and explain method of teaching Literature (61\%).This is followed by the teacher assigning chapters to be read from home and discussed in class (37\%). There is also the use of the lecture method (27.18\%). Results further indicate that when a majority or all the students possessed the prescribed texts, teachers used read aloud and explain method (43.1\%) as well as the lecture method (25.8\%) and discussion method (1.8\%). Similarly, when either a few or none of the students possessed the prescribed texts, teachers used read aloud and explain methods (36.4\%) followed by the lecture method (28\%). It was concluded that lack of text possession by the students and teachers' inflexible use of methods in spite of varying contexts of teaching and learning are strong pointers to students declining performance in prose Literature. Government and parents should take realistic measures to provide prescribed texts for students while teachers should be encouraged to use innovative methods that are consistent with the teaching and learning contexts.
\end{abstract}

Keywords: text possession; pedagogical practices; engagement; prose literature

\section{Introduction and Background}

Education world wide is considered a priceless asset and the corner stone of human and national development. This probably explains the reason why much prominence is given to access and quality in education. Many developing countries, including Nigeria, are engaged in the continuous struggle to strike a balance between access and quality in their education development strategies. Over the years, education in Nigeria has persistently contended with the challenges of low quality and unwholesome examination practices. The inevitable effect of this trend is the poor 
performance of students in almost all the subjects on the school curriculum including Literature in English. The dwindling performance of students in school examinations has been linked to a number of factors such as the use of a foreign language as a medium of instruction, low teacher quality, students' partial knowledge of English Language, ineffective pedagogical practices, students' lack of seriousness, lack of instructional materials as well as students' inability to purchase the prescribed texts.

Concerns about how best to teach, what to teach and how to ensure that students have learnt have remained recurring issues in education (Beach, Appleman, Hynd and Wilhelm, 2006). It is believed that success in teaching in the classroom largely depends on the teacher because they are responsible for stimulating students' interest and in directing the mood and flow of class activities (Wilhelm, 2006). Literature, however, is included in the school curriculum for developing not only cognitive, affective and psychomotor components of the individual but also reading skills and literary competence of the learners. In consonance with this view, Akyel and Yalsin (1990), report that texts could be treated as art and a resource for language development. Besides, Akyel and Yalcin (1999) observe that students seem to feel that the most effective literary form for helping them (the students) develop their linguistic skills and cultural awareness is the novel. In Lazar's (1990) view, using a novel with the English Language learner provides a rich source of pedagogic activities. The study of literature is inextricably interwoven with language and reading.

The inseparable relationship between language and literature has continued to drive the controversy as to whether these subjects should be taught separately or as one. Part of the argument was also whether literature would be taught in non-native situations since it was believed that non-native learners of English might find it difficult to cope with. However, one of the purposes of foreign language teaching then, was to enable learners have access to literary works (Widdowson, 1984). One of the contentions in favour of using literature in the English Language classroom is that literature contains the best use of the English Language by the best authors and as such would rob off on the students exposed to it. This expected advantage is hindered by the fact that most literary texts are too difficult for non-native students to access. In spite of the unresolved role of literature in language teaching, some approaches have been adopted by teachers in the teaching of literature. These comprise the language, the cultural and the personal growth models (Carter and Long, 1991).

The language model is based on the premise that language and literature are two sides of a coin. It is further argued that since literature is made from language, exposing students to it would increase their linguistic and literary competence. The language based approach enables learners to utilize various strategies used in language teaching as well as access text in a systematic manner in order to identify specific linguistic features (Savvidou, 2004). While the approach has some potential for developing students' language ability, it compromises the purpose of teaching literature which is mainly to promote enjoyment of the literary experience through students' emotional involvement and personal response to the text.

The cultural model perceives literature as the embodiment of the peoples' culture. In this capacity, literature is seen as a medium for transmitting the accumulated knowledge and ideologies of the learner's culture and that of other people. Through this approach, students are encouraged to understand the universality of human cultures and ideologies and appreciate those different from their own. It is, however, observed that not all works of literature are pure and genuine representations of the social and historical reality of their time especially as literature is a form of art, the language and content of which is deliberately manipulated to suit the needs of the writer (Brumfit and Carter, 1986). The cultural approach which is synonymous with the traditional approach is teacher-centred and in its pedagogic orientation, favours the transmission or lecture method of instruction. In this approach, attention is centred on the literary work and the teacher takes the centre stage in exploring the text from its social, political, literary and historical contexts. Information about the text is given from critical and literary works, biographical facts about the authors and synopsis of the texts. This approach denies the learner of the opportunity to make a personal response to the text which is the essence of the study of literature.

The personal growth model emphasizes the need for students' personal engagement with literary texts. The approach focuses on the use of language in the text, the cultural context as well as encourage learners to express their feelings, ideas, connect the text to their personal experiences and ultimately to respond to texts. The reader's engagement and interaction with the text is accorded great priority. The reader's response and engagement with texts further provides opportunity for learners to share their personal interpretation and meanings with others and by so doing, deepen their understanding of the text. It seems none of these approaches to teaching literature provides a comprehensive and more effective method of teaching literature. The language, cultural, and personal growth models differ in terms of their focus, as they perceive the text as: useful for grammatical and structural analysis; cultural artefact; a stimulus to 
personal growth activities respectively (Savvidou, 2004). In the light of the inadequacies associated with each approach, Duff and Maley (1990) recommends the integration of the three approaches as a more effective way of teaching literature especially in an ESL/EFL context.

The pedagogic practice of teachers in Nigeria in the teaching of literature varies among the three approaches discussed with greater inclination to the traditional or cultural approach. This is one factor responsible for students' poor performance in Literature examinations. Students' poor performance in Literature could also be traced to their low proficiency in English Language and reading comprehension. For instance, the West African Examinations Council (WAEC) Chief Examiners' reports for the past ten years on Literature in English reveal that candidates have problems with understanding the English Language and expressing themselves in it. They also lack in-depth knowledge of the prescribed texts because they preferred to read 'short notes' or study guides instead of the actual texts. Specifically, the WAEC Chief Examiners’ Report (2000) on prose Literature-in-English states that:

The performance of the candidates is far below that of the previous years - this is both in terms of the knowledge of the text and the command of the English language. The dismal standard of English language is alarming. It is evident that the candidates did not understand that texts, hence they could not respond to them because they lacked the medium, English language (p.27).

Similarly, the WAEC Chief Examiners' Report for 1997 on prose Literature-in-English states that:

The greatest weakness of candidates was their lack of in-depth knowledge of the prescribed texts. Many of the candidates did not show evidence of having read the texts because a majority of them merely wrote scanty answers memorized from 'short notes' (p.38).

Further support is given to the connection between low proficiency in English Language, lack of interest in reading and poor performance in Literature. For instance, Oyetunde and Muodumogu (1999) describe reading as problematic to students in the Nigerian school system as many of them fail to learn to read and many more are unable to read to learn, a situation they portrayed as reading failure.

Literature in English is a subject in the Senior Secondary School curriculum in Nigeria. It is divided into - prose, poetry and drama. A total of two novels and two drama texts (African and non-African for each genre) and twelve poems (six African and six non-African) are prescribed by the examining bodies for the Senior School Certificate Examination - The West African Examinations Council (WAEC) and National Examinations Council (NECO). To do well in the examinations, students are expected, in addition to attending classes regularly, to read the texts themselves as many times as possible so as to be familiar with their contents. Hence, the importance of purchasing the prescribed texts in Literature in English is underscored. It is perhaps one of the subjects with the highest number of prescribed texts to be read in the Senior Secondary School.

\section{Statement of the Problem}

Literature-in-English is written in a foreign language medium and studied by learners who lack adequate proficiency in the language. Besides, for most of the students, reading is problematic and hence they tend to shy away from it. The students' willingness to engage in reading is further marred by inability to purchase texts. Moreover, teachers tend to use ineffective methods and strategies. Previous researches on Literature teaching focused on methods, strategies and problems of teaching the subject in secondary schools. However, there is dearth of studies on text possession and on whether students' text possession affects teachers' method and the extent of text utilization among students. Hence, this study investigated the extent of students' possession of the prescribed Literature texts and teachers' pedagogical practices in Prose Literature classrooms. It also examined the influence, if any, of students' extent of text possession on teachers' pedagogical practices.

\section{Research Questions}

The study has the following research questions:

1. What is the extent of students' possession of the prescribed Literature texts?

2. What method(s) do teachers generally adopt in teaching Prose Literature? 
3. What method(s) of teaching Prose Literature do teachers use when a majority or all the students possess the prescribed texts in class?

4. What method(s) of teaching Prose Literature do teachers use when a few or none of the students possess the prescribed texts in class?

\section{Methodology}

The study adopted the descriptive survey design. The population for the study was Senior Secondary School II Literature in English teachers and their students in Ibadan metropolis. The participants in this study were one hundred (100) teachers of Literature in English and their five hundred (500) students. Purposive and random sampling techniques were employed to select participants for the study. From the eleven local government areas in Ibadan, 6 local government areas were randomly selected (Ibadan North, Ibadan North West, Egbeda, Akinyele, Lagelu and Ibadan South West). From each local government, 16 schools were randomly selected for the purpose of the Teachers' Questionnaire thus making a total of 96 schools and in each school at least one teacher was selected for the study. Again, from each of the six local government areas, at least three schools were purposively chosen for observation. A total of twenty (20) teachers were each observed twice, bringing the observation total to forty (40). In addition, from each school observed, twenty-five (25) students responded to the Students' Questionnaire, bringing the total number to five hundred (500). The criteria for the selection of schools for observation were:

i. They must be public schools.

ii. The number of Senior Secondary School II students offering Literature in each of the schools must be, at least, twenty (20).

iii. The schools must be teaching the prose genre of Literature as at the time of observation.

iv. The schools must be willing to participate in the study.

v. The schools must have registered students for the Senior School Certificate Examinations for at least the past five (5) years.

Three instruments were used for data collection, namely: Teachers' questionnaire titled Questionnaire on How Teachers' Organize the Teaching of Prose Literature (QOTOTPL), Students' questionnaire titled Questionnaire on Students' Possession and Engagement with the Recommended Prose Literature Texts (QSPERPLT) and classroom observation schedule: Classroom Observation Schedule for the Teaching of Prose Literature (COSFPL).

The Teachers' Questionnaire sought answers from teachers on the methods they adopt in teaching Prose Literature. The Students' Questionnaire was designed to discover students' level of text possession for the three genres of Literature while the classroom observation schedule was designed to record the activities of students and teachers during Prose Literature lessons to determine the pedagogic practices of the teachers observed.

\subsection{Validity and Reliability of the Instruments}

The instruments for the study were prepared by the researcher and subjected to expert advice of some lecturers in the field of Literature teaching, both from the Faculty of Education and the Faculty of Arts, University of Ibadan, to read for content and face validity.

In order to ascertain the reliability of the instruments, the Students' Questionnaire and the Teachers' Questionnaire were trial tested for reliability and co-efficients of 0.76 and 0.75 were obtained respectively.

For the observation instrument, 2 Literature teachers similar to those involved in the study were each observed twice by the researcher and another trained observer while teaching the prose genre of Literature in schools similar to those used in the study, but were excluded from the study sample. The results were analyzed using Scott's Formula and yielded an inter-rater reliability of 0.84 .

\subsection{Procedure}

The researcher personally collected the data for the study in the sample schools used. The researcher provided guidance for the respondents while they were filling in the questionnaires to avoid errors. The researcher observed the Literature lessons which were delivered during the normal periods in the school timetable. The targeted activities of teachers and students were recorded using a tally each time they occurred.

\subsection{Data Analysis}

Data from the observation and questionnaires were analyzed using descriptive statistics involving frequency counts 
and percentages.

\section{Results}

The results of the study are presented in order of the research questions as follows:

Research Question 1: What is the extent of students' possession of the prescribed Literature texts?

Results from the Students' Questionnaire revealed that students who possess the prescribed Literature texts in all the genres are fewer than those who do not. However, text possession ranked high among the following: African Novel (38.6\%), African drama (37\%), Anthology of non-African poems (35\%), study guide on African novel (50.6\%) and teacher's notes (65.6\%). Details are shown in Table 1.

Table 1. Extent of Students’ Text Possession

\begin{tabular}{lll}
\hline \multicolumn{1}{c}{ Texts } & Have (\%) & Do Not Have (\%) \\
\hline 1. African novel & $193(38.6)$ & $307(61.4)$ \\
2. Non- African novel & $135(27.0)$ & $365(73.0)$ \\
3. African drama & $185(37.0)$ & $315(63.0)$ \\
4. Non-African drama & $143(28.6)$ & $357(71.4)$ \\
5. Anthology of African poems & $110(22.0)$ & $390(78.0)$ \\
6. Anthology of non-African poems & $175(35.0)$ & $375(75.0)$ \\
7. Study guides on African novel & $253(50.6)$ & $247(49.4)$ \\
8. Study guides on non-African novel & $155(31.0)$ & $345(69.0)$ \\
9. Study guides on African drama & $139(27.8)$ & $361(72.2)$ \\
10. Study guides on non-African drama & $145(29.0)$ & $355(71.0)$ \\
11. Study guides on African novel & $170(34.0)$ & $330(66.0)$ \\
12. Study guides on non-African novel & $179(35.2)$ & $324(64.8)$ \\
13. Teacher's notes & $328(65.6)$ & $171(34.2)$ \\
\hline
\end{tabular}

Results from the Teachers' Questionnaire corroborates the result from the Students' Questionnaire. It revealed that $60.16 \%$ of the students do not possess the prescribed African novel while $65.51 \%$ of the students do not possess the prescribed non-African novel. Further details are presented in Table 2.

Table 2. Extent of Students’ Possession of the Prescribed African and Non-African Novels

\begin{tabular}{rlll}
\hline \multicolumn{1}{c}{ Text } & & Students With Texts (\%) & Students Without Texts (\%) \\
\hline 1. & African novel & $1,644(39.84)$ & $2,482(60.16)$ \\
2. & Non-African novel & $1,423(34.48)$ & $2,703(65.51)$ \\
& Total & 4,423 & \\
\hline
\end{tabular}

Research Question 2: What method(s) do teachers generally adopt in teaching Prose Literature?

Responses from the Teachers' Questionnaire revealed that reading chapter-by-chapter in class with explanations given by the teacher (61\%) is the preferred method of teaching prose. It is followed by assigning chapters for students to read from home and then discussion in class (37\%), giving summaries of chapters as notes for students to copy (19\%), and assigning tasks to students in groups (1\%). The predominant methods are therefore reading chapter by chapter with explanations given by the teacher and discussion method. Details are presented in Table 3. 
Table 3. Methods of Teaching the Novel

\begin{tabular}{|c|c|c|c|c|}
\hline \multicolumn{2}{|r|}{ Methods } & \multirow{2}{*}{$\begin{array}{l}\text { Freq } \\
37\end{array}$} & \multirow{2}{*}{$\begin{array}{l}\% \\
37\end{array}$} & \multirow{2}{*}{$\begin{array}{l}\text { Rank } \\
\text { 2nd }\end{array}$} \\
\hline a. & Assign chapters for students to read from home and then discuss in class. & & & \\
\hline b. & $\begin{array}{l}\text { Read chapter-by-chapter in class and explain to students (reading done by } \\
\text { students and teacher) }\end{array}$ & 61 & 61 & $1^{\text {st }}$ \\
\hline C. & Give summaries of chapters to students as notes and they copy & 19 & 19 & $3^{\text {rd }}$ \\
\hline d. & $\begin{array}{l}\text { Assign tasks to students in groups and they present their work to the whole } \\
\text { class }\end{array}$ & 1 & 1 & $4^{\text {th }}$ \\
\hline
\end{tabular}

Responses from the Students' Questionnaire corroborate those obtained from the Teachers' Questionnaire. The students' responses revealed that the dominant method of prose instruction favored by teachers is the Read Aloud and Explain method (65\% for teachers doing the reading alone and $45.6 \%$ for reading done by both the teacher and students). It is followed by the lecture method (teacher gives summary and students copy) with $35.2 \%$ and the discussion method with 31.6\%. Further details are presented in Table 4.

Table 4. Students’ Response on Teachers’ Methods of Teaching Prose Literature

\begin{tabular}{|c|c|c|c|}
\hline $\mathrm{S} / \mathrm{N}$ & Question & $\begin{array}{l}\text { Yes } \\
\text { (\%) }\end{array}$ & $\begin{array}{l}\text { No } \\
\text { (\%) }\end{array}$ \\
\hline
\end{tabular}

18 Which of these represent the way your teacher teaches the novel in class?

a Reads aloud and explains

326

174

b Teacher and students read aloud and teacher explains

c Teacher gives summary and students copy

d Silent reading by students followed by oral questions and discussions

The data collected from the observation schedule supports those from the Teachers' and Students' Questionnaires. It showed that the most dominant method of teaching the novel is Read aloud and explain (39.76\%). It is followed by the Lecture method (27.18\%) and the Discussion method (1.02\%). The use of Group Activities was not observed. Table 5 presents teachers' activities in the observed schools. The following items in the table deal with methods of teaching Prose Literature:

Read Aloud and Explain Method: Items 2 and 5

Lecture Method: Items 3, 4 and 6

Discussion Method: Items 7-9, 11 and 14

Group Method: Item 15 
Table 5. Observed Teachers’ Activities during Prose Literature Lessons

$\mathrm{N}=40$

\begin{tabular}{|c|c|c|c|}
\hline $\mathrm{S} / \mathrm{N}$ & Teachers' Activities & Freq & $\%$ \\
\hline 1 & Initiate warm-up activities & 38 & 7.71 \\
\hline 2 & Ask students to read aloud and explain intermittently & 171 & 34.69 \\
\hline 3 & Lecture/talk non-stop & 126 & 25.56 \\
\hline 4 & Give a summary of the text to be read & 3 & 0.61 \\
\hline 5 & Read aloud (model) & 25 & 5.07 \\
\hline 6 & Give a summary of what is read & 5 & 1.01 \\
\hline 7 & Ask students to read silently & 0 & 0 \\
\hline 8 & Ask students to justify their answers & 0 & 0 \\
\hline 9 & Ask questions to provoke ideas (discussion) & 3 & 0.61 \\
\hline 10 & Ask close-ended questions & 16 & 3.25 \\
\hline 11 & Give guiding questions & 2 & 0.41 \\
\hline 12 & Ask questions that elicit information, ideas, facts, etc. from, text & 102 & 20.69 \\
\hline 13 & Ask questions that lead to emotional, attitudinal and aesthetic response to the work & 2 & 0.41 \\
\hline 14 & Give prompts/cues & 0 & 0 \\
\hline 15 & Divide the students into groups and assign tasks & 0 & 0 \\
\hline 16 & Give take-home assignments (with guides) & 6 & 1.22 \\
\hline \multirow[t]{2}{*}{17} & Use of ICT related media & 0 & 0 \\
\hline & Total & 493 & 100 \\
\hline
\end{tabular}

On a general note, item 1 showed that prose teachers most often use warm-up activities before beginning the lesson. A frequency of 38 (7.71\%) was recorded as against 40 for all the observations. Also, from item 16, it is clear that the frequency of giving assignments on prose lessons is low (6 i.e. 1.22\%). Finally, teachers do not make use of ICT related media when teaching prose (item 17).

Research Question 3: What method(s) of teaching Prose Literature do teachers use when a majority or all the students possess the prescribed texts in class?

Results from the classroom observation of teachers showed that the Read Aloud and Explain method ranks highest with $43.11 \%$ while the Lecture method $(25.77 \%)$, Discussion method $(1.78 \%)$ and Group method $(0 \%)$ rank $2^{\text {nd }}$, $3^{\text {rd }}$ and $4^{\text {th }}$ respectively. Further details are presented in Table 6. For the items in Table 6 that indicate methods of teaching Prose Literature, please refer to the description of items in Table 5.

Table 6. Teachers’ Activities in Observed Schools where a Majority or All the Students Possess the Prescribed Texts $\mathbf{N}$ (No. of observations) $=\mathbf{2 0}$

\begin{tabular}{|c|c|c|c|}
\hline $\mathrm{S} / \mathrm{N}$ & Teachers' Activities & Freq & $\%$ \\
\hline 1 & Initiate warm-up activities & 19 & 8.44 \\
\hline 2 & Ask students to read aloud and explain intermittently & 87 & 38.67 \\
\hline 3 & Lecture/talk non-stop & 54 & 24.0 \\
\hline 4 & Give a summary of the text to be read & 1 & 0.44 \\
\hline 5 & Read aloud (model) & 10 & 4.44 \\
\hline 6 & Give a summary of what is read & 3 & 1.33 \\
\hline 7 & Ask students to read silently & 0 & 0 \\
\hline 8 & Ask students to justify their answers & 0 & 0 \\
\hline 9 & Ask questions to provoke ideas (discussion) & 2 & 0.89 \\
\hline
\end{tabular}




\begin{tabular}{llll}
\hline 10 & Ask close-ended questions & 9 & 4.0 \\
11 & Give guiding questions & 2 & 0.89 \\
12 & Ask questions that elicit information, ideas, and facts from text & 37 & 16.44 \\
13 & Ask questions that lead to emotional, attitudinal and aesthetic response to the work & 2 & 0.89 \\
14 & Give prompts/cues & 0 & 0 \\
15 & Divide the students into groups and assign tasks & 0 & 0 \\
16 & Give take-home assignments (with guides) & 1 & 0.44 \\
17 & Use of ICT related media & 0 & 0 \\
& Total & 225 & 100 \\
\hline
\end{tabular}

Generally, teachers in schools where a majority or all the students possess the prescribed texts in class use warm-up activities as shown in item 1 (19 times out of 20 observations).Items 16 shows teachers rarely gave take-home assignments $(0.44 \%)$ while the use of ICT related media is noticeably absent.

Research Question 4: What method(s) of teaching Prose Literature do teachers use when a few or none of the students possess the prescribed texts in class?

The results from observed schools where a few or none of the students possess the prescribed texts revealed that the predominant method of prose instruction is Read Aloud and Explain (36.39\%) followed by Lecture method (27.99\%), Discussion method (0.36\%) and Group method (0\%) respectively.

In terms of general classroom practice, item 1 revealed that the teachers used warm-up activities 19 (6.99\%) out of the 20 times they were observed. Item 16 shows a higher percentage of take-home assignments (1.84\%) than that of schools where a majority or all the students possess the prescribed texts in class. Item 17 shows absence of the use of ICT related media. Details are presented in Table 7.

For items in Table 7 that indicate the various methods observed, please refer to the description of items in Table 5.

Table 7. Teachers' Activities in Observed Schools where a few or none of the Students Possess the Prescribed Texts $\mathrm{N}$ (No. of observations) $=20$

\begin{tabular}{llll}
\hline S/N & \multicolumn{1}{c}{ Teachers' Activities } & Freq & \multicolumn{2}{c}{$\%$} \\
\hline 1 & Initiate warm-up activities & 19 & 6.99 \\
2 & Ask students to read aloud and explain intermittently & 84 & 30.88 \\
3 & Lecture/talk non-stop & 72 & 26.47 \\
4 & Give a summary of the text to be read & 2 & 0.74 \\
5 & Read aloud (model) & 15 & 5.51 \\
6 & Give a summary of what is read & 2 & 0.74 \\
7 & Ask students to read silently & 0 & 0 \\
8 & Ask students to justify their answers & 0 & 0 \\
9 & Ask students to provoke ideas (discussion) & 1 & 0.36 \\
10 & Ask close-ended questions & 7 & 2.57 \\
11 & Give guiding questions & 0 & 0 \\
12 & Ask questions that elicit information, ideas, facts, etc. from texts & 65 & 23.89 \\
13 & Ask questions that lead to emotional, attitudinal and aesthetic response to the work & 0 & 0 \\
14 & Give prompts/cues & 0 & 0 \\
15 & Divide the students into groups and assign tasks & 0 & 0 \\
16 & Give take-home assignment(with guides) & 5 & 1.84 \\
17 & Use of ICT related media & 0 & 0 \\
& Total & 272 & 100 \\
\hline
\end{tabular}




\section{Discussion of Findings}

Findings revealed that a majority of students do not possess the prescribed Literature texts. In separate studies, Olasele (2007) and Nwaigwe (2007) found students' level of text possession to be inadequate. This shows that non-possession of the prescribed texts in Literature in English by students is a trend which appears to be persistent. Explanations advanced for students' lack of text possession include inability of the students to purchase the prescribed texts ranked highest (48\%). From the students' perspective, using Literature as a subject to complete the number of subjects they offer for the Senior Secondary School Examinations (51\%) is their reason for not reading the prescribed texts. This is not a motivator for studying Literature which could likely affect their attitude towards the subject. When students have a positive attitude towards a subject, this will likely be translated into high academic achievement (Pintrich and Schunk, 2000).

Text possession is central to students experiencing the literary work. Students who chose Literature just to complete the number of subjects in the Senior Secondary Certificate Examinations (SSCE) are not interested in the subject. Consequently, they lack the motivation to study it effectively. Again, poverty on the part of parents may be a genuine reason for not acquiring the texts. Text possession is a necessary precondition for the reader's active engagement with text. Another source of reading frustration for students of Literature is inability to comprehend what was read. $34.2 \%$ of the students admit that they do not understand the texts when they read. Teachers should provide sufficient prior knowledge especially in relation to language related problems.

Again, findings on teaching methods revealed that Literature classrooms are predominantly teacher -dominated. There was no noticeable difference in teaching methods in observed schools where a majority or all the students possessed the prescribed texts and in observed schools where a few or none of the students possessed the prescribed texts in class. This confirms an earlier observation by Ogunnaike (2002) who described the majority of Literature teachers' methods as routine and monotonous; Literature lessons are taught as comprehension lessons with the take-out-your-book-and-read approach. It appears that teachers are rigid in their application of teaching methods and strategies. Their methods are not sensitive to the local context of teaching and learning such as text possession and language difficulties. For Baines (2008), the overwhelmingly dominant instructional approach in treating a text is simply (1) assign a text to be read, (2) discuss the text in class, (3) have students respond to questions about the text, and (4) give an exam or worksheet. This method, he further explained assumes (not a valid assumption) that students actually read and understand the prescribed text. Such an approach, Baines surmises, can be meaning free for students, especially those who do not listen well. In a related study depicting the nature of activities carried out in the Literature classroom, Hwang and Embi (2007) explained that reading aloud, comprehension exercises (in form of WH-questions) and teacher re-telling and explanation of the literary texts were the three activities evident in all the classroom observations. An excuse teachers give for using this method is that very few or no student at all in their classes has the prescribed texts so they have to resort to reading and explaining most often by themselves. If this were true for teachers in this study, then there should have been a difference in teaching methods in schools where a majority or all the students possessed the prescribed texts and in schools where a few or none of the students possessed the prescribed texts in class. Rather, the most preferred method observed was the Read aloud and explain method irrespective of the number of students who possessed the texts in class.

On the classroom practices of the observed teachers, it was revealed that teachers used warm-up activities (38 times out of the 40 observations) before proceeding to the lesson for the day. However, these activities were predominantly revision of the previous lessons. Only 2 teachers observed used the background of the author as an introductory activity and this was because they were introducing the novel to the students for the first time. Another teacher introduced the lesson by differentiating between drama (the genre they had finished studying) and prose, the genre they were about to study. Teachers thus equate warm-up activities with revision of the previous lesson only. In so doing, they downplay the importance of getting students in the mood - an activity which could lead to better students' engagement with the text - before proceeding with the day's lesson. As observed by Guthrie, Wigfield, Humenick, Perencevich, Taboada and Barbosa (2006), reading and comprehension of text is relatively high when students are curious about the topic because of situational interest generated after performing a stimulating task related to the text. Worthy of mention also is the fact that the classroom arrangement of a majority of the schools observed was such that the teacher's movement is restricted to the front of the class. Even in schools where it was possible for the teacher to move round the class, they did not. They preferred to stay in front of the class and dish out information to the students. It thus would be impossible for these teachers to effectively carry along every student in the class in this way. 


\section{Conclusion and Recommendations}

The study has reaffirmed the fact that majority of students in the Senior Secondary School offering Literature in English do not possess the prescribed literary texts. It has further shown that teacher-centered methods of teaching still dominate the Literature classrooms. Teachers are not likely to teach Literature effectively without being flexible in their pedagogic approaches and without active engagement of students with texts within the context of text possession and willingness to read. In the light of the adverse implications of these for students, it is recommended that:

Parents/guardians should, in spite of the harsh economy, prioritize their needs and ensure their children/wards have access to the prescribed texts, not just in Literature, but in all subjects offered. Students on their part should ensure they read and re-read the prescribed texts for better understanding instead of depending solely on the teacher's notes or short notes.

Literature teachers should introduce novelty and variety of methods and activities into the classroom. Teachers should not be so predictable that every time they walk into the class, the students already know what to expect. Teachers should provide a variety of learning experiences and resources, including technology (where possible). Teaching literature should involve pre-reading, while-reading and post-reading activities. Pre-reading activities are warm-up activities which are used to stimulate students' interest in the text to be read and to activate existing schemata. While-reading activities are designed to help students interact meaningfully with the text; it is used to promote dialogue between reader and writer (Berardo, 2006). Post-reading activities are used to encourage students to reflect on what they have read and stimulate further interaction with text. Activities such as predicting, re-writing, gap filling, role-playing others can make the teaching and learning of literature interesting and enjoyable (Abraham, 2010). Similarly, Muller (2006) advocates for the use of films in teaching literature as this can bring students to higher levels of thinking and challenge all levels of students.

However, for teachers to effectively use a variety of activities in their lessons, they must be well prepared. Teachers should not assume that students can read prose texts on their own and understand them since the writing of prose is close to the pattern of everyday speech. Rather, they should adopt student-centered methods of teaching to encourage students' engagement with text. They should break the monotony of teacher-centered methods of teaching Literature. Teachers should realize that reading texts for literary experience is different from reading them for information. Thus, they should be engaged in aesthetic teaching. They should emphasize students' personal responses to the text. The students should be made to feel that they are not just discussing something far removed from them. Rather, they should see how Literature and the text relate to their everyday lives.

The power of good leadership and administration in schools are crucial to create conducive teaching atmosphere for teachers (Ahmad, 2008). Bringing in novel activities into the Literature classroom by teachers may at times require the co-operation of school authorities. For example, going to a theatre to watch a filmed or dramatized version of the text or even watching same in class. Hence, it is recommended that school authorities do everything in their power to support the Literature teacher whenever such support is needed. Also, school authorities should enforce the possession of texts as a requirement for students who wish to offer Literature. Where teachers had the backing of the school authorities, it was discovered that the students responded by purchasing the prescribed texts.

In schools with libraries, the school administrators should ensure the protection of the materials in it. They could even liaise with well-meaning individuals, corporate bodies or non-governmental organizations to help in stocking their libraries with the recommended Literature texts. This will go a long way in helping indigent students who may not be able to purchase these texts.

There is a lot the government can do to promote the effective teaching of Literature in secondary schools. First, the government should employ more qualified Literature in English teachers. It was observed that teachers who teach Literature are extremely few in number with some of them teaching the subject in addition to teaching English Language or performing other administrative functions in the case of the Vice-Principals. A situation where a single teacher teaches the three arms of the senior secondary school does not make for effective teaching. Second, government should provide libraries in all public schools and ensure that existing ones are stocked with the relevant books including the prescribed Prose Literature texts. This would help students get access to text they otherwise might be unable to purchase or find. Finally, the government should incorporate a reading programme into the curriculum so that students can develop good reading habits, an invaluable tool in the study of Literature. 


\section{References}

Abraham, P. A. (2010). Teaching literature through language - Some considerations. In B. Mllikarjun, S. Mohanlal, B. A. Sharada, A. R. Fatihi, L. Gusain, K. karunakaran, J. M. Bayer, \& S. M. Ravichandran. (Eds). Language in India: Strength for today and bright hope for tomorrow, 10, 78-90.

Ahmad, F. (2008). Presage, context, process and product: Influencing variables in an ESL context. GEMA Online Journal of Language Studies, 8(1), 1-21.

Akyel, A., \& Yalcin, E. (1990). Literature in the EFL class: A study of goal-achievement incongruence. ELT Journal, 44, 174-180. http://dx.doi.org/10.1093/elt/44.3.174

Baines, L. (2008). A teacher's guide to multisensory learning: Improving literacy by engaging the senses. USA: Association for Supervision and Curriculum Development.

Beach, R., Appleman, D., Hynd, S., \& Wilhelm, J. (2006). Teaching literature to adolescents. New Jersey: Routledge.

Berardo, S.A. (2006). The use of authentic materials in the teaching of reading. The reading Matrix, 6(2), 60-69.

Brumfit, C., \& Carter, R. (1986). Literature and language teaching. Oxford: Oxford University Press

Carter, R. A., \& Long, M. N. 1991. Teaching literature. New York: Longman

Chambers, E., \& Gregory, M. (2006). Teaching and learning English Literature. London: SAGE Publications Ltd.

Duff, A., \& Maley, A. (1990). Literature. Oxford: Oxford University Press.

Guthrie, J. T., Wigfield, A., Humenick, N.M., Perencevich, K. C., Taboada, A., \& Barbosa, P. (2006). Influences of stimulating tasks on reading motivation and comprehension. The Journal of Educational Research, 99(4), 232-245. http://dx.doi.org/10.3200/JOER.99.4.232-246

Hwang, D., \& Embi, A. (2007). Approaches employed by secondary school teachers to teaching the Literature component in English. Jurnal Pendidik dan Pendidikan, 22, 1-23.

Lazar, G. (1990). Using novels in the language learning classroom. ELT Journal, 44, $204-214$. http://dx.doi.org/10.1093/elt/44.3.204

Muller, V. (2006). Film as film: Using movies to help students visualize literary theory. The English Journal, 95(3), 32-38. http://dx.doi.org/10.2307/30047041

Nwaigwe, C. P. (2007). Text possession and preparation for the senior school certificate Literature in English examination in some schools in Ibadan, Oyo State. B.Ed Project, University of Ibadan.

Ogunnaike, J. (2002). Challenges of the teaching and learning of literature in Nigerian secondary schools. In A, Lawal, I. Isiugo-Abanihe \& N. I.Ohia. (Eds), Perspectives on applied linguistics in language and literature, pp. 334-344. Ibadan: Sterling-Horden Publishers.

Olasele, O.G.F. (2007). What teachers and students do to prepare for the senior secondary school certificate examination in Literature in English in some schools in Lagos. B. Ed Project, University of Ibadan.

Pintrich, S., \& Schunk, P. (2002). Motivation in education. New Jersey: Merrill.

Savvidou, C. (2004). An integrated approach to teaching literature in the EFL classroom. The Internet TESL Journal, 10(12), 1-6.

The West African Examinations Council. (May/June 1997). Senior School Certificate Examination Chief Examiners' Reports. Yaba, Lagos: Test Development Division.

The West African Examinations Council. (May/June 2000). Senior School Certificate Examination Chief Examiners' Reports. Yaba, Lagos: Test Development Division.

Widdowson, G. H. (1984). Learning purpose and language use. Oxford: Oxford University Press. 